\title{
Conus arteriosus: an anatomic and terminologic evaluation
}

\author{
Dündar Kaçar, Çağatay Barut \\ Department of Anatomy, Faculty of Medicine, Biilent Ecevit University, Zonguldak, Turkey
}

\begin{abstract}
Objectives: The aim of this study was to evaluate the anatomy and terminology for the conus arteriosus, thereby revealing possible differences among various sources of this information.

Methods: Twenty-four textbooks, nine anatomy atlases, and six original articles related to terminology were examined. The term "conus arteriosus," first used in Terminologia Anatomica, published in 1998, was also evaluated.

Results: Conus arteriosus is a part of the right ventricle (ventriculus dexter). Physicians refer to this structure as the 'infundibulum'. Taking into account the three-dimensional aspect of the right ventricle, its outer surface is considered to be the conus arteriosus. This structure is supplied by branches of the right and left coronary arteries which are called the conus arteries. Thus, utilization of the term "conus artery" supports the aforementioned suggestion.

Conclusion: In case the term "conus arteriosus" falls out of preference for this structure as a whole, the nomenclature used for this structure in anatomy atlases must be corrected. This point is of importance for instructors and students.
\end{abstract}

Keywords: conus arteriosus; infundibulum; right ventricle; sternocostal surface

Anatomy 2014;8:40-44, (C) 2014 TSACA

\section{Introduction}

The heart has long been of interest to mankind. Illustrations of the heart and circulatory system can be found in ancient Egyptian papyri. ${ }^{[1]}$ The heart is still of interest today and is subject to a variety of studies. Thus, all structures that comprise the heart have been named terminologically. ${ }^{[2]}$ However, some differences are present between the basic and clinical medical sciences with respect to terminology for the structures constituting the heart. Some differences may also be present between textbooks and atlases in presentation of these structures. ${ }^{[3]}$ The aim of this study was to evaluate the anatomy and terminology for conus arteriosus, thereby revealing possible differences among various sources.

\section{Materials and Methods}

Twenty four textbooks of basic and clinical medical sciences, nine anatomy atlases, and six original articles published between 1961 and 2013 on terminology were examined. Terminologia Anatomica (1998) where the term "conus arteriosus" was first used was also assessed.

\section{Results}

The sternocostal (anterior) surface of the heart (facies sternocostalis) can be exposed via a median sternotomy incision. It is formed mainly by the right ventricle (ventriculus dexter). ${ }^{[4,5]}$ Right ventricle (ventriculus dexter) is divided into three components rather than the traditional "sinus" and "conus" parts. These are the inlet, apical trabecular and outlet parts. ${ }^{[4]}$ The inlet portion of the right ventricle (ventriculus dexter) contains and is limited by the tricuspid valve (valva tricuspidalis) and its tension apparatus. The apical trabecular component extends out to the apex of the heart. The outlet component is a complete muscular structure which supports the leaflets of the pulmonary valve (valva trunci pulmonalis). ${ }^{[4,6-8]}$ Incision of the convex area just below the pulmonary valve (valva trunci pulmonalis) (Figure 1) reveals the sub- 
pulmonary part of the right ventricular cavity. Cardiac surgeons refer to this site as the outlet of the right ventricular cavity. ${ }^{[4]}$ Physicians refer to this area as the infundibulum, whereas anatomists refer to it as the conus arteriosus. ${ }^{[9-18]}$ These two terms are sometimes used together. $^{[5,8,18-25]}$ In certain anatomy textbooks only infundibulum is preferred. ${ }^{[26-28]}$

Cardiology and cardiovascular surgery textbooks designate conus arteriosus as a structure within the right ventricle. Two basic discrepancies have been found in these. First, the cone-shaped, smooth-surfaced area near the opening of the pulmonary trunk (pulmonary orifice) is defined as the "conus arteriosus" or "infundibulum" in anatomy textbooks, ${ }^{[18-21,23,25,29,30]}$ but only as "infundibulum" in cardiovascular surgery or cardiology textbooks. ${ }^{[6]}$ Second, the term "infundibulum" is not preferred in anatomy atlases ${ }^{[31-33]}$ which refer to the "conus arteriosus", the convex area on the anterior surface of the right ventricle contributing to the sternocostal aspect of the heart at the origin of the pulmonary trunk.

In addition, no structure in the interior right ventricle is termed the "conus arteriosus" or "infundibulum". ${ }^{[31-33]}$ In Netter's Atlas of Human Anatomy, "conus arteriosus" is marked on both the exterior and interior parts of the right ventricle. ${ }^{[34-36]}$ In Terminologia Anatomica, both "conus arteriosus" and "infundibulum" are used..$^{[2]}$

Figure 1. Schematic illustration of the sternocostal surface of the heart (facies sternocostalis). CBRCA: conus branch of right coronary artery (ramus coni arteriosi); AV: annulus of Vieussens, $\mathrm{b}$ : Area supplied by the right and left conus branches.

\section{Discussion}

In the majority of textbooks, the terms "conus arteriosus" and "infundibulum" are used synonymously to define the cone-shaped, smooth-surfaced area near the opening of the pulmonary trunk (pulmonary orifice) (Figure 2). The conus branch of the right coronary artery (ramus coni arteriosi) and the conus branch of the anterior interventricular branch of the left coronary artery (ramus coni arteriosi) supply the area indicated as the "conus arteriosus" in anatomy atlases. ${ }^{[31-38]}$ These two vessels anastomose to form the "anulus of Vieussens" (Figure 1). Accordingly, a terminological denomination can be created in relation to the site marked "a" in Figure 2, taking into account the threedimensional morphology. Thus, the same term used for site "a" can be used for the site marked "b" on the anterior surface of the right ventricle in Figure 2. The same site is shown as a three-dimensional cone in Figure 3, and the anterior surface of this cone is marked "a". Designation of the site marked "b" in Figure $\mathbf{2}$ and the site marked "a" in Figure $\mathbf{3}$ as "conus arteriosus" (=infundibulum) would ensure consistency with the terminology used for the vessels. Around twenty-second day of intrauterine life, a single straight cardiac tube is formed. This cardiac tube can be divided into five chambers. Bulbus cordis is the second subdivision among these five chambers. The others are truncus arteriosus, common ventricle, common atrium and sinus venosus. The bulbus cordis is divided into infundibulum and aortic vestibule (vestibulum aortae)

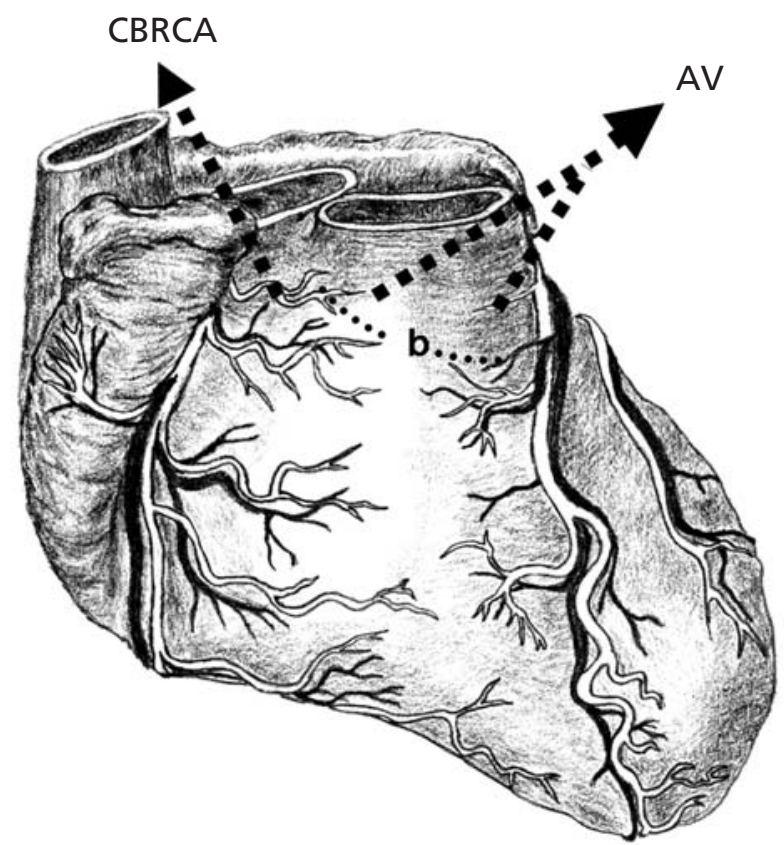




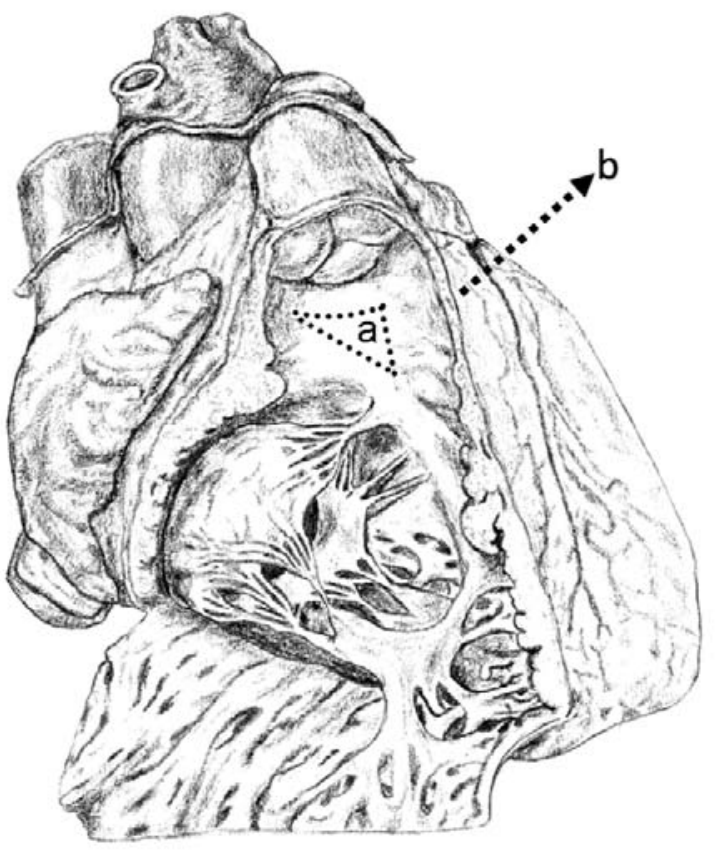

which are outflow tracts of right and left ventricle respectively. ${ }^{[5,39]}$ Wilcox et al. ${ }^{[4]}$ described an infundibular morphology related with the ventricular outflow tracts. The outflow tracts of the two ventricles together make a complete cone of musculature, which has parietal and septal components, along with a component adjacent to the atrioventricular junction. The anterior free walls of the out-

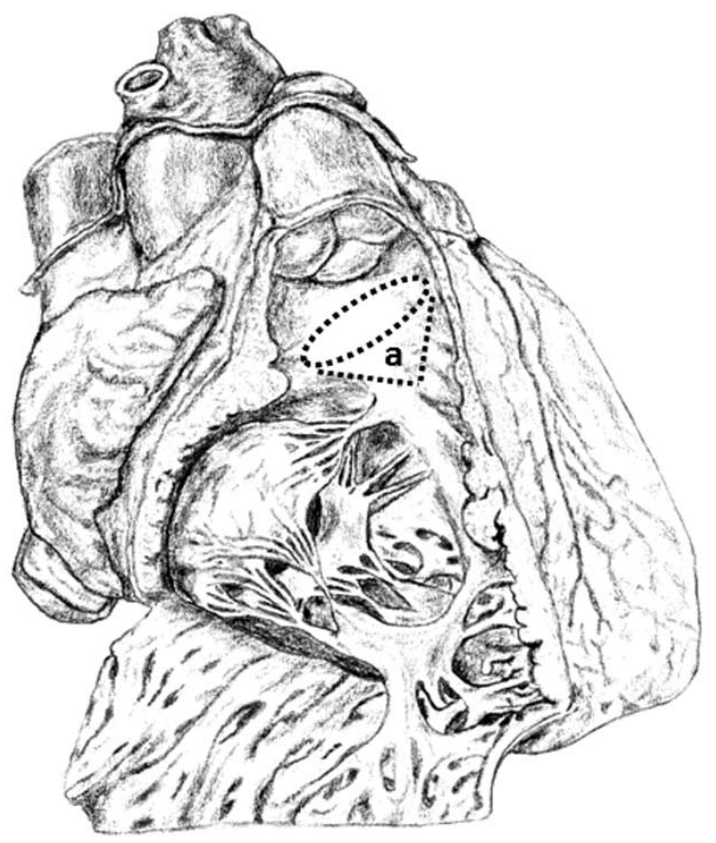

Figure 2. Schematic illustration of the interior of the right ventricle from the sternocostal aspect. a: flat part of the right ventricle (ventriculus dexter) close to the opening of the pulmonary trunk (truncus pulmonalis); b: exterior part of the right ventricle (ventriculus dexter) marked as the conus arteriosus in certain anatomy atlases. flow tracts constitute the parietal component ${ }^{[4]}$ similar to the site marked "a" in Figure 3. Site marked "a" in Figure 3 actually is a part of the aforementioned parietal component. Their explanation supports the usage of the term "conus arteriosus".

Malouf et al. ${ }^{[8]}$ used both terms for the outflow of the right ventricle and explained each term depending on

Figure 3. Three-dimensional schematic illustration of the conus arteriosus (infundibulum) from the sternocostal aspect of the heart. a: anterior surface of the cone-shaped part. 
shape (conus means "cone; infundibulum means "funnel"). Furthemore ,they stated the outflow of the right ventricle as a smooth-walled muscular subpulmonary channel. In the study of Merrick et al., ${ }^{[0]}$ infundibulum was referred as "subpulmonary infundibulum" and stated to be the continuation of the right ventricle free wall.

Thus, conus arteriosus is a structure in the right ventricle. This term is used synonymously with "infundibulum," and clinicians prefer "infundibulum" for this structure. Depending on the anatomy textbooks and clinical textbooks of cardiac surgery and cardiology, this structure should be considered in three dimensions. Therefore this structure is not only a convex area on the exterior surface of the right ventricle close to the pulmonary trunk but also outflow part of the right ventricle related with interior of the heart. The issue related with terminology of this structure can be answered only with the consensus of anatomists and clinicians, which should be obtained by creating a terminology committee with participants from both fields. Based on our findings, we believe that this would be an appropriate arrangement. Taking into account the daily practice needs of clinicians the term "infundibulum" can be preferred for this structure. If the term "conus arteriosus" is not preferred for this structure, the terminology used in anatomy atlases should be changed accordingly. Moreover this should be taken into consideration for the next revision of "Terminologia Anatomica". This modification would be very important not only for lecturers, but also for medical students.

\section{Acknowledgement}

We would like to express our sincere graditute to Dr. Burak Güney for his drawings.

\section{References}

1. Mesut R. Kardiyovasküler anatomi. In: Duran E, ed. Kalp ve damar cerrahisi. 1. baskı. İstanbul: Çapa Tip Kitabevi; 2004. p. $37-41$.

2. Federative Committee on Anatomical Terminology (FCAT). Terminologia Anatomica. Stuttgart: Thieme; 1998.

3. Kaçar D, Barut Ç. Veins of the heart: an evaluation of the terminology. Türk Gögüus Kalp Damar Cerrahisi Dergisi 2011;19:529-32.

4. Wilcox BR, Cook AC, Anderson RH. Kalbin cerrahi anatomisi. [Çev. Ed. Oran B]. 3. Baskı. Ankara: Güneş Tıp Kitabevleri; 2010. p. 14-129.

5. Kulkarni NV. Clinical anatomy (A Problem Solving Approach). 2nd ed. New Delhi: Jaypee Brother Medical Publishers; 2012. p. $238-57$.

6. Wilcox BR, Anderson RH. Surgical anatomy of the heart. In: Baue AE, ed. Glenn's thoracic and cardiovascular surgery. Vol 2. 6th ed. Stanford, Connecticut: Appleton and Lange; 1995. p. 1544-45.
7. Cook AC, Wilcox BR, Anderson RH. Surgical anatomy of the heart. In: Sellke FW, ed. Sabiston and Spencer's surgery of the chest. 10th ed. Philadelphia: Elsevier Saunders; 2010. p. 697-710.

8. Malouf JF, Edwards WD, Tajik AJ, Seward JB. Functional anatomy of the heart. In: Fuster V, Alexander RW, O'Rourke RA, eds. Hurst's the heart. 11th ed. New York: Mc-Graw-Hill; 2004. p. $65-7$.

9. Arıncı K, Elhan A. Anatomi. Cilt 2. 4. baskı. Ankara: Güneş Kitabevi; 2006. p. 6.

10. Zeren Z. Anatomi. İstanbul: Filiz Kitabevi; 1966. p. 196.

11. Odar IV. Anatomi. Cilt 2. 7. baskı. Ankara: Hacettepe Kitapçılık; 1986. p. 403-4.

12. Popma JJ, Bittl J. Coronary angiography and intravascular ultrasonography. In: Braunwald, Zipes DP, Libby P, eds. Heart disease. 6th ed. Philadelphia: WB Saunders; 1988. p. 399-400.

13. Kachlik D, Baca V, Bozdechova I, Cech P, Musil V. Anatomical terminology and nomenclature: past, present and highlights. Surg Radiol Anat 2008;30:459-66.

14. Message MA, Anderson RH. Towards a new terminology for clinical anatomy, with special reference to the heart. Clin Anat 1996; 9:317-29.

15. Anderson RH, Brown NA. The anatomy of the heart revisited. Anat Rec 1996;246:1-7.

16. Watler DC, Wynter L. Cor triventriculare: infundibular stenosis with subdivision of the right ventricle. Br Heart J 1961;23: 599-602.

17. McKinley M, O'Loughlin VD. Human anatomy. 2nd ed. Boston: McGraw-Hill; 2008. p. 632-3.

18. Drake RL, Vogl W, Mitchell AWM. Dorland's/Gray's Anatomi Cep Atlası.[Çev. Ed. İlgi S]. Ankara: Güneş Kitabevi; 2010. p. $100-101$.

19. Sancak B, Cumhur M. Fonksiyonel anatomi: Baş-boyun ve iç organlar. 3. baskı. Ankara: ODTÜ Yayıncılık; 2004. p. 146.

20. Moore KL, Dalley AF. Kliniğe yönelik anatomi. [Çev. Ed. Şahinoğlu K]. 4. baskı. İstanbul: Nobel Tıp Kitabevleri; 2007. p. $127-8$.

21. Dauber W. Sistematik resimli anatomi sözlüğü. [Çev. Ed. Yıldırım M]. 4. Türkçe baskı. İstanbul: Nobel Tip Kitabevleri; 2007. p. 226.

22. Gatzoulis MA. Thorax. In: Standring S, ed. Gray's anatomy. 40th ed. New York: Churchill Livingstone Elsevier; 2008. p. 964-1020.

23. Gökmen FG. Sistematik anatomi. İzmir: Güven Kitabevi; 2003. p. 247-8.

24. Çimen A. Anatomi. 6. baskı. Bursa: Uludağ Üniversitesi Güçlendirme Vakfi; 1996. p. 196.

25. Drake RL, Vogl W, Mitchell AWM. Gray's anatomy for students. 1st ed. New York: Churchill Livingstone Elsevier; 2005. p. 164-5.

26. Snell RS. Klinik anatomi. [Çev. Cumhur M]. 3. baskı. Ankara: Palme Yayıncilik; 2003. p. 15.

27. Ellis H. Clinical anatomy: Applied anatomy for students and junior doctors. 11th ed. Oxford: Blackwell Publishing; 2006. p. 29-32.

28. Singh I. Textbook of anatomy. Volume 3. 5th ed. New Delhi: Jaypee Brother Medical Publishers; 2011. p. 406.

29. Yıldırım M. Resimli sistematik anatomi. 1. baskı. İstanbul: Nobel Tip Kitabevleri; 2013. p. 318.

30. Yıldırım M. Resimli anatomi sözlüğü. 1. Baskı. İstanbul: Nobel Tip Kitabevleri; 2013. p. 174-5. 
31. Ferner H, Staubesand J. Sobotta insan anatomisi atlası. [Çev. Arıncı K]. Cilt 2. 2. baskı. Ankara: Atlas Tıp Kitapçılık; 1985.

32. Ferner H, Staubesand J. Sobotta/Becher atlas of human anatomy. Vol. 2. 9th English ed. München: Urban \& Schwarzenberg; 1975.

33. Putz R, Pabst R. Sobotta insan anatomisi atlası. [Çev. Elhan A]. Cilt 2. İstanbul: Beta Basım A.Ş; 2006.

34. Netter FH. Atlas of human anatomy. 5th ed. Philadelphia: Saunders; 2010.

35. Netter FH. İnsan anatomi atlası. [Çev. Ed. Cumhur M]. 3. Baskı. İstanbul: Nobel Tip Kitabevleri; 2005.
36. Netter FH. The Netter collection of medical illustrations. [Çev. Ed. Erol Ç]. Vol. 5. Ankara: Güneş Tip Kitabevleri; 2007.

37. Turgut HB. Anatomi uygulama kitabı. Ankara: MN Medikal \& Nobel; 2010.

38. Arıncı K, Elhan A. Anatomi (Dolaşım sistemi). 1. Baskı. Ankara: Türkiye Klinikleri Yayınevi; 1993.

39. Schoenwofl GC, Bleyl SB, Brauer PR, Francis-West PH. Larsen's human embryology. 4th ed. Philadelphia: Churchill Livinstone Elsevier; 2009. p. 349.

40. Merrick AF, Yacoub MH, Ho SY, Anderson RH. Anatomy of the muscular subpulmonary infundibulum with regrad to the Ross procedure. Ann Thorac Surg 2000;69:556-61.

Correspondence to: Çağatay Barut, MD, PhD

Department of Anatomy, Faculty of Medicine,

Bülent Ecevit University, Kozlu, 67600, Zonguldak, Turkey

e-mail: cagbarut@yahoo.com

Conflict of interest statement: No conflicts declared. 